\title{
ARTE RUPESTRE Y COMPLEJIDAD SOCIAL DURANTE EL PERÍODO INTERMEDIO TARDÍO EN LA SUBREGIÓN DEL RÍO SALADO (NORTE DE CHILE)**
}

\author{
ROCK ART AND SOCIAL COMPLEXITY DURING THE LATE INTERMEDIATE \\ PERIOD, SALADO RIVER SUBREGION (NORTH OF CHILE)
}

\author{
Marcela A. Sepúlveda R. ${ }^{1,2}$
}

\begin{abstract}
Se presentan los resultados del estudio de varios sitios de pinturas y grabados adscritos al período Intermedio Tardío, de la subregión del río Salado (Región de Antofagasta, norte de Chile). Su análisis iconográfico y contextual nos permite identificar varias modalidades estilísticas peculiares para este período. Sus características formales y de emplazamiento nos permiten ir elucidando su función en relación a los procesos socioculturales acontecidos en la región en dicho período, caracterizados por profundos cambios sociales, económicos y políticos, en otras palabras, por una gran complejidad social. Se destaca finalmente el rol del individuo quien en este marco de complejidad da cabida a su creatividad, dando lugar a una gran variedad de formas de hacer o reproducir dichos patrones de representación o modalidades estilísticas.
\end{abstract}

Palabras claves: arte rupestre, período Intermedio Tardío, estilo e individuo.

We present the results of the study of several rock art sites assigned to the Late Intermediate Period in the basin of the Salado River (Region of Antofagasta, North of Chile). Iconographic and contextual analysis allows us to identify several stylistic modalities unique to this period. The characteristics of form and emplacement help us to elucidate the function of these motifs in relation to the profound social, economic and political changes relating to increasing social complexity that were occurring in the region during this period. We then consider the role of human agency, which is what ultimately gives rise to the variations observed in the modes of representation and stylistic modalities expressed.

Key words: Rock art, Late Intermediate Period, style and individual.

En se voulant solitaire, l'artiste se berce d'une illusion peut-être féconde, mais le privilège qu'il s'accorde n'a rien de réel. Quand il croit s'exprimer de façon spontanée, faire œuvre originale, il réplique à d'autres créateurs passés ou présents, actuels ou virtuels. Qu'on le sache ou qu'on l'ignore, on ne chemine jamais seul sur le chantier de la création (Lévi-Strauss 1979:127).

Tras dos décadas de estudios sistemáticos acerca del arte rupestre de la región de Antofagasta, y más particularmente el localizado en la subregión del río Salado, diferentes trabajos permiten precisar una secuencia cronológica marcada por la presencia de diversos estilos rupestres (Gallardo et al. 1999, entre otros). Sin embargo, cuando revisamos más en detalle lo definido para el período Intermedio Tardío (900-1.450 d.C.) nos percatamos que a pesar de haberse planteado ciertas interpretaciones al respecto, hasta ahora los estudios siguen siendo escasos. Por un lado, existen trabajos que tratan de los grabados que se integran en los grandes asentamientos de la región (Gallardo y Vilches 1995; Vilches y Uribe 1999); por otro, se reconocen trabajos en relación a las pinturas presentes en sitios más pequeños, tipo alero (Gallardo et al. 1999; Sepúlveda 2002a).

En este caso, nos abocamos al universo de representaciones localizado en los sitios "secundarios" y el integrado a los principales asentamientos del Intermedio Tardío, ¿Cuáles son sus características

* Este estudio fue presentado en el simposio sobre Arte Rupestre de los Andes, realizado en el $52^{\circ}$ Congreso Internacional de Americanistas, Sevilla, julio de 2006. La edición de los artículos seleccionados para este número de la Revista estuvo a cargo de Marcela Sepúlveda y Jean Guffroy.

1 Departamento de Antropología, Universidad de Tarapacá, 18 de Septiembre 2222, Casilla 6D, Arica, Chile. msepulveda@uta.cl, marcelaasre@gmail.com

2 Centro de Investigaciones del Hombre en el Desierto, Arica, Chile. 
formales y/o estilísticas? ¿Existe un estilo o varias modalidades estilísticas para este período? ¿Dónde se localiza? y ¿Qué relaciones mantienen estas representaciones con los procesos socioculturales del Período también conocido como de Desarrollos Regionales?

En términos clásicos, el Período Intermedio Tardío se inicia tras el cese de las influencias de Tiwanaku en el área Centro-Sur andina, con la consecuente aparición de numerosos señoríos locales (Lumbreras 1974; Schiappacasse et al. 1989). En la subregión del río Salado, este período se define por la existencia de una mayor complejidad social, respecto a períodos anteriores y marcada, entre otros, por un cambio en el patrón de asentamiento (Adán y Uribe 1995; Adán et al. 1995; Uribe 2002; Uribe et al. 2004), en el cual se reconoce la presencia de aldeas, estancias y ocupaciones en aleros que gravitan en torno a grandes asentamientos, en algunos casos identificados como pukaras (Castro et al. 1991). Esta modificación de la ocupación del espacio y el aumento en el tamaño de los asentamientos permiten suponer la existencia de un crecimiento demográfico y la presencia de una mayor diferenciación y jerarquización social, con la presencia de autoridades capaces de ordenar a una población en aumento y de estructurar el uso de una mayor mano de obra. A las diversas formas de construcción arquitectónicas residenciales se suma la presencia de varios patrones funerarios: en aleros, en cistas y la presencia de chullpas, además de un registro material cerámico diverso. En conjunto, estas manifestaciones hacen presumir la existencia de múltiples poblaciones coexistiendo en la subregión del río Salado, durante el Período Intermedio Tardío o de Desarrollos Regionales, reagrupadas en cuanto a su manifestación cerámica en dos componentes culturales: uno Loa-San Pedro y otro Altiplánico (Uribe 1997:259). Cronológicamente, se precisa una secuencia de dos momentos para el Intermedio Tardío: un primer momento marcado por la presencia de una población local (900-1.300 d.C.), y un segundo caracterizado por la intrusión de manifestaciones altiplánicas coexistiendo con las locales (1.300-1.450 d.C.; ver Aldunate 1991). Más recientemente, Uribe (2002) y con sus colaboradores (2004) precisan dos fases para el primer momento del Intermedio Tardío: la Fase Yaye-Solor (9001.100 d.C.) y la Fase Turi-Quitor (1.100-1.300 d.C.). Los autores, en efecto, observan el paso de un patrón de asentamiento tipo estancia a uno tipo núcleo-estancia con el surgimiento de las grandes aldeas, y complementado con un mayor énfasis en las tecnologías agrícolas.

En términos de interacción entre los diferentes grupos que coexisten durante los Desarrollos Regionales se plantea una movilidad donde priman "patrones de tráfico de menor distancia [no existiendo]... la búsqueda de un eje mayor y único convergente" (Núñez y Dillehay 1995 [1979]:107).

Las interpretaciones existentes, al presente, en relación con las manifestaciones pintadas rupestres de la subregión del río Salado sugieren que se vincularían con el proceso de territorialidad existente en este período (Gallardo et al. 1999; Sepúlveda 2002a), principio de segmentación espacial definido en torno a cuatro localidades principales: Turi, Topain, Likan y Ayquina (Ayala 1999). En regiones vecinas, otra hipótesis relaciona las manifestaciones del Período Intermedio Tardío con la movilidad de caravanas de llamas, interpretación en la cual el arte rupestre jugaría un rol de señalética o de indicador de rutas vinculadas al tráfico de caravanas (Berenguer 1994a, 1994b, 1999, 2004a; Núñez et al. 1997).

Asumiendo los límites impuestos por la imposibilidad, hasta ahora, de fechar las manifestaciones rupestres y basados en una atribución cronológica relativa, intentamos ordenar la gran variedad de figuras y motivos registrados en sitios cuyas ocupaciones se adscriben mayoritariamente al Intermedio Tardío. Más aún, intentamos formular probables relaciones entre las expresiones rupestres de este período y los procesos socioculturales que lo caracterizan.

\section{Antecedentes de Estudios del Arte Rupestre de la Cuenca del Río Loa}

Las más antiguas referencias acerca de las pinturas rupestres del norte de Chile surgen tan tempranamente como se van descubriendo los primeros habitantes de esta región (Castro 1997). Sin embargo, sólo a partir de la segunda mitad del siglo XX hallamos referencias más claras sobre estas representaciones del desierto de Atacama, principalmente en los sectores precordilleranos andinos. Entre ellos destacan los trabajos de Barthel et al. (1959), Le Paige (1957-58), Mostny (1966), Niemeyer (1968), Orellana (1963), Rydén (1944) y Spahni (1976) quienes contribuyen en dar a conocer la presencia de estas particulares manifestaciones, 
convirtiéndose en objeto de especial interés sólo a partir de la década de 1980, cuando se inician los primeros trabajos de registro regional y su ordenamiento (Aldunate et al. 1983; Berenguer et al. 1985).

Posteriormente, superando la tendencia inicial de estos estudios descriptivos e intentos interpretativos, ligados a prácticas ceremoniales y/o rituales de los antiguos habitantes de la región, más específicamente desde principios de los noventa, se desarrollan nuevos estudios sistemáticos. Estos se concentran principalmente en el Loa superior (Alto Loa y río Salado), y se dedican a la identificación o precisión de estilos de arte rupestre (grabados y pintados), intentando establecer su adscripción cronológico-temporal y su relación con los procesos socioculturales que caracterizan cada período (Berenguer 1999, 2004b; Gallardo 2001, 2004a; Gallardo y Vilches 1998; Gallardo et al. 1996 [1998], 1999; Montt 2004, 2005).

En el Alto Loa, se definen inicialmente estilos (Aldunate et al. 1983). Luego y quizás a modo de revisar lo inicialmente propuesto, se definen "fases de arte rupestre" correspondiente al ordenamiento espacio-tiempo de las representaciones, planteándose para una segunda etapa la discriminación de estilo (Berenguer et al. 1985:91). Actualmente, los estilos identificados para el Alto Loa (Berenguer 1999 y 2004b) son definidos a base de variables relacionadas con características temáticas (Berenguer 2004a:425), atendiendo únicamente al aspecto formal de las representaciones, pues no precisa criterios tales como técnicas, emplazamiento, contextos, por ejemplo.

En la subregión del río Salado la mirada hacia las pinturas rupestres ha sido influenciada por los trabajos de historiadores del arte tales como Gombrich, Berger y Washburn, entre otros, marcando entonces una diferencia con los demás trabajos realizados en las cuencas del río Loa y del Salar de Atacama (Núñez et al. 1997; 2006). Estas influencias han generado una aproximación distinta sobre las representaciones rupestres, concibiéndolas como imágenes con las cuales se expresan ciertas cualidades visuales, en un ejercicio de reproducción de la realidad y de creatividad que presuponen la elección de ciertas cualidades del referente real (Gallardo 2001, 2004a; Gallardo y Vilches, 1998; Gallardo et al. 1999; Montt 2002). Es así como los estudios no se enfocan solamente en identificar conjuntos de figuras y/o motivos por sus semejanzas, sino que buscan entender cómo se expresan y se conjugan ciertas decisiones gráficas en una imagen y en un conjunto de imágenes. Qué se muestra y cómo se muestra, se tornan en preguntas claves para aproximarse a las manifestaciones rupestres; entendiendo que las decisiones gráficas efectuadas son consecuencia o se definen en un determinado contexto que, en otros términos, alude a ser característicos o peculiares de un momento histórico-cultural particular y en relación con los procesos socioeconómicos y políticos definidos para ese tiempo. Finalmente, aproximaciones simbólicas, estructurales y marxistas en relación a la búsqueda de significados e interpretaciones contextuales, algunas veces basadas en la información proveniente de referencias etnográficas y/o etnohistóricas complementan el enfoque estilístico (Gallardo et al. 2006).

Siguiendo esta línea, en este trabajo y previo el ejercicio de identificar estilos para el Intermedio Tardío se revisa el concepto de estilo tal como ha sido aplicado e interpretado, hasta ahora, evaluando nuevas posibilidades interpretativas en función de los resultados obtenidos.

\section{Hacia una definición del concepto de estilo...}

Para efectuar nuestra revisión del arte rupestre del período Intermedio Tardío, consideramos la definición de estilo previamente utilizada por Gallardo et al. (1996 [1998]), es decir:

Un estilo en arte rupestre es considerado [...] como un conjunto de normas o convenciones gráficas que caracterizan la producción de un universo iconográfico coherente desde el punto de vista formal, aunque variable dentro de sus propios límites. Traducido a criterios taxonómicos, esto significa que un estilo de arte rupestre se presenta siempre como un grupo politético de atributos (Davis 1990), donde cada individuo del conjunto comparte muchos de los atributos del total registrado, aunque de manera variable tanto en su distribución como en su frecuencia. Esto, sin embargo, supone definir un conjunto de atributos cuyas distribuciones y frecuencias muestren decisiones altamente estandarizadas, es decir, normas de manufactura que en contextos sociales de especialización productiva aparecerán 
como distribuciones sesgadas hacia una misma (o semejante) medida y, por tanto, distintas a una curva normal cuya distribución es el resultado del azar (Gallardo et al. 1996 [1998]:354-355).

En términos metodológicos esta definición de estilo nos permite ordenar una variedad de figuras, identificando conjuntos que comparten ciertos atributos relacionados con variables definidas a partir de las formas de representación y/o de composición de los paneles. Otras aproximaciones podrían, también, considerar aspectos tecnológicos ligados a su producción o relaciones espaciales de la construcción de una figura, de un panel o de un sitio (p.ej., Troncoso 2002:139).

Desde estos supuestos, se han considerado, hasta ahora, variables como las formas de representación, el referente, la animación de las figuras, las técnicas de ejecución (lineal, areal o combinados) y la composición de los paneles logrando identificar varios estilos: Taira-Tulan, Confluencia, Cueva Blanca y Quebrada Seca (Gallardo et al. 1999), además de varios conjuntos dispersos para el período Intermedio Tardío (Sepúlveda 2006).

Entendemos que con esta concepción de estilo, considerada una herramienta de análisis o un "estilo instrumentalizado", se define la existencia de varios conjuntos de figuras que comparten ciertas normas, presumiendo que tras esta concepción existe un sistema normativo mayor o estructura (Hodder 1982), en el cual el artista escoge sólo ciertos elementos de esas normas, explicando de paso la posible heterogeneidad existente al interior de un estilo. Sin embargo, al trabajar en un nivel macrorregional resulta poco visible la caracterización de la variabilidad que en realidad subyace al conjunto de representaciones (para discusión semejante ver Hodder 2000:26).

El uso de una definición de estilo como un conjunto politético de rasgos, tal como se ha hecho en el estudio de las pinturas rupestres de la subregión del río Salado, ha permitido introducir el análisis de múltiples variables formales y de composición. Los conjuntos identificados como estilos luego han sido interpretados como correspondientes a diversos momentos de la prehistoria o a diversos grupos de una sociedad, entendiendo que tras la variabilidad subyacente se entiende que los individuos de una sociedad puedan compartir muchos de los atributos del total registrado, aunque de manera variable tanto en su distribución como en su frecuencia. Quizás el problema visualizado en la actualidad ha sido la insistencia en considerar los resultados estadísticos, y por tanto, los estilos a partir de la presencia de similitudes generales, impidiendo visualizar las particularidades o diferencias, por ejemplo, entre las figuras y los paneles. La utilización de una visión macrorregional quizás tampoco ha contribuido en este sentido, pues no permite dilucidar las especificidades presentes en cada sitio y en cada localidad. Es, por ende, útil recordar la necesaria distinción entre la definición de un estilo, como se le identifica metodológicamente, y luego la interpretación que se hace de él.

Sin embargo, agregamos, y coincidiendo con Sackett (1982), que es muy poco probable que los valores o normas definidos se hallen en otro contexto que el definido al momento de su hallazgo. En otras palabras, en una sociedad, se escoge dentro de una amplia gama de posibilidades funcionales y formales alternativas similares, y una vez escogida una forma es muy poco probable que se escoja otra. Así, con Sackett se recalca en la discusión acerca del estilo la apertura hacia la capacidad de decisión de los grupos. Una vez escogida dentro de una gama de alternativas, su elección y la definición de convenciones determinarán, a la vez que son determinados por los campos de estructura, o habitus, que condiciona totalmente a los miembros de un grupo social como planteara Bourdieu (1979). Así, es probable que un estilo sea consecuencia de una sociedad en un momento específico de la prehistoria.

Más allá de intentar visualizar las normas que rigen un conjunto de figuras resulta, además, imposible alejarnos de la necesidad de comprender la función que cumple el estilo en una sociedad, en un grupo sociocultural definido, en un período o en una secuencia histórico-cultural dada o en la interacción existente entre diferentes grupos que comparten un mismo territorio geográfico. Con esta afirmación entendemos también que un estilo tiene un rol activo, ya sea en términos de ser el producto de cierta actividad humana, de contribuir a la interacción entre diferentes grupos o como forma de comunicación (Hegmon 1992; Jochim 1983; Sackett 1977; 1985, 1990; Wiessner 1983, 1985, 1990; Wobst 1977), rescatándose primordialmente la capacidad de decisión, la posibilidad de elegir por parte de una sociedad entre alternativas funcionales semejantes. 
Por ende, apostamos a que el estilo es un hecho con dimensión, es una práctica social que involucra una sociedad pero también individuos, y cuya práctica no es un hecho simplemente pasivo, sino activo. A su vez, en el estilo se involucran aspectos tan diversos, como la ideología, los procesos socioeconómicos, políticos, simbólicos o funcionales y también de recreación personal, por citar algunos (Hodder 1982; Voss y Young 1995, ver discusión semejante y ampliada en Sepúlveda 2011).

Ahora, nos permitimos matizar en alguna medida el concepto de estilo, adhiriendo a la reciente propuesta de Aschero (2006) al referirse al término de modalidad estilística, en el sentido:

de reunir patrones de representación, temas, selecciones de emplazamiento y uso de los soportes semejantes, ocurridos en una trama de relaciones relativamente sincrónica y preservando la posibilidad de incluir estilos diferentes que coexisten dentro de cada modalidad. [...] en otros términos modalidad despliega la variabilidad estilística potencial existente en una microregión pero articulando aquellos elementos que se comparten quebrada a quebrada, esto es, información coparticipada dentro de un determinado lapso (Aschero 2006:110).

Con esta definición tenemos la capacidad de precisar que tras la variabilidad subyacente en el Intermedio Tardío lo que se identifica estadísticamente son diferentes Modalidades, las que encierran diferentes Estilos propios de una localidad, de un grupo determinado o de individuos específicos dentro de una sociedad compleja y multiétnica característica de los Desarrollos Regionales. Así, metodológicamente adherimos a lo planteado por Gallardo et al. (1996 [1998]) en el sentido de valorizar los estudios estadístico-multivariables; sin embargo, matizamos las interpretaciones de los resultados obtenidos. Con esto no negamos la existencia de estilo, sino que recalcamos la necesidad de rescatar la variabilidad existente pese a la existencia de ciertas normas comunes.

Con estos antecedentes generamos para el período Intermedio Tardío, caracterizado por una importante interacción entre diferentes grupos que coexisten en un mismo espacio y/o territorio (Uribe y Adán 2005; Uribe et al. 2004), las siguientes interrogantes: ¿Existe una relación entre el arte rupestre y los procesos que caracterizan ese período? ¿Tienen las modalidades estilísticas definidas para este período un rol comunicativo?

Para responder esta pregunta abordaremos nuestro trabajo con las siguientes expectativas:

(1) si entendemos el arte rupestre como un elemento activo en las interrelaciones e interacciones existentes entre diferentes grupos, entonces es posible pensar en que en un espacio definido existan principios de territorialidad o mecanismos que permiten legitimar la presencia de un grupo en determinada área, posibilitando el acceso a sus recursos. Si tal fuera la situación es esperable la existencia de un arte rupestre heterogéneo.

(2) Sin embargo y a su vez, si observamos la coexistencia de diferentes grupos en los diferentes sitios de la subregión del río Salado y por ende en un mismo espacio, donde sus manifestaciones culturales se entremezclan sobre la base de dos componentes culturales netamente diferentes (componentes Loa-San Pedro y Altiplánico), podemos suponer la presencia de patrones de representación similares, y por tanto un arte rupestre homogéneo, dada la necesidad de compartir y explotar los recursos de un mismo gran territorio.

¿Cuál de estas situaciones se manifestará en la subregión del río Salado? y ¿cuál es el efecto en la prehistoria local?

\section{Localización y Emplazamiento}

\section{La subregión del río Salado}

Situada entre los $2.500 \mathrm{msm}$ y la alta Cordillera de los Andes, la subregión del río Salado aparece como una zona privilegiada en un territorio marcado por una extrema aridez. Se trata de una cuenca hidrográfica (Figura 1) situada en la antesala de la cordillera (2.500-4.000 msm), e interrumpida por numerosas quebradas profundas (zona de quebradas altas) por donde fluyen temporal o permanentemente diversos ríos y cursos de agua, permitiendo la existencia de microclimas favorables al desarrollo de la vida humana y a sus diferentes actividades de subsistencia (agricultura y caza en el pasado). La presencia de aguas subterráneas y la existencia de vegas son otros importantes recursos explotados en la región para actividades tales como la ganadería. 
En esta zona, la mayoría de las manifestaciones rupestres registradas se emplazan sobre las paredes verticales de las quebradas o al interior o exterior de aleros formados en las laderas de quebradas, siendo la mayoría de los paneles orientados hacia el norte y el oeste. Los contextos asociados (Tabla 2) a las representaciones rupestres indican ocupaciones, por un lado estacionales (actividades agrícolas o ganaderas) en el caso de los aleros rocosos, y por otro, permanentes, pues algunos paneles se encuentran formando parte de asentamientos complejos, aunque las representaciones se hallen en espacios usados como recintos funerarios (Likan) o como lugar de almacenaje-collcas-(Incahuasi Inca). Sólo en algunos casos se reconocen paneles sin asociaciones arqueológicas precisas, aunque se observó la proximidad de senderos o áreas de tránsito (El
Diablo, Los Mosquitos). La cantidad de paneles en cada sitio resulta muy variable (Tabla 1) y no se relaciona necesariamente con su presencia en sitios habitacionales con mayor densidad de ocupación.

\section{Universo de Estudio y Modalidades Estilísticas}

Nuestro estudio contempló el análisis de 14 sitios (Figura 1) y un total de 316 figuras antropomorfas y zoomorfas, existiendo escasos motivos geométricos.

Del total de las figuras, $47,8 \%$ representan camélidos, 44,6\% figuras antropomorfas, 5,4\% a otras especies animales como aves principalmente, y $2,2 \%$ no fueron identificables. En cuanto a técnica, se distinguieron figuras pintadas $(88,3 \%)$, otras

Tabla 1. Descripción general de los sitios analizados.

General description of the sites analyzed.

\begin{tabular}{|c|c|c|c|c|c|}
\hline Piso Ecológico & $\begin{array}{c}\text { Localización } \\
\text { Geográfica }\end{array}$ & Sitio & Emplazamiento & Técnica & $\begin{array}{l}\text { Cantidad de } \\
\text { Paneles }\end{array}$ \\
\hline \multirow{3}{*}{$\begin{array}{l}\text { Quebradas } \\
\text { intermedias }\end{array}$} & \multirow{3}{*}{$\begin{array}{l}\text { Quebrada del } \\
\text { río Salado }\end{array}$} & $\begin{array}{l}\text { Agua Mineral } \\
\text { (2 Loa 60) }\end{array}$ & Alero (lado norte) & Pintura & 15 \\
\hline & & $\begin{array}{l}\text { El Diablo } \\
(2 \text { Loa 50) }\end{array}$ & Pared (lado sur) & $\begin{array}{l}\text { Pintura, grabado y } \\
\text { grabado pintado }\end{array}$ & 23 \\
\hline & & $\begin{array}{l}\text { Los Mosquitos } \\
\quad(2 \text { Loa 61) }\end{array}$ & Alero (lado sur) & Pintura & 5 \\
\hline \multirow{9}{*}{$\begin{array}{l}\text { Quebradas } \\
\text { altas }\end{array}$} & $\begin{array}{l}\text { Quebrada de } \\
\text { Incahuasi }\end{array}$ & $\begin{array}{l}\text { Incahuasi Inca } \\
\quad(2 \text { Loa } 71 ; \\
\text { 02CAS/CAS67) }\end{array}$ & $\begin{array}{c}\text { Alero y pared de } \\
\text { quebrada (lado sur) }\end{array}$ & Pintura & 11 \\
\hline & $\begin{array}{l}\text { Quebrada de } \\
\text { Pilpila }\end{array}$ & $\begin{array}{c}\text { Pilpila } \\
\text { (2 Loa 89) }\end{array}$ & Alero (lado sur) & Pintura & 13 \\
\hline & \multirow{4}{*}{$\begin{array}{l}\text { Quebrada de } \\
\text { Cupo }\end{array}$} & $\begin{array}{l}\text { Cueva Roja } \\
\text { (2 Loa 88) }\end{array}$ & Alero (lado este) & Pintura & 5 \\
\hline & & $\begin{array}{c}\text { El Suri } \\
(2 \text { Loa } 75)\end{array}$ & $\begin{array}{c}\text { Aleros y pared de } \\
\text { quebrada (lado este) }\end{array}$ & Pintura & 1 \\
\hline & & $\begin{array}{l}\text { La Cueva } \\
(2 \text { Loa } 78)\end{array}$ & Alero (lado este) & Pintura & 1 \\
\hline & & $\begin{array}{l}\text { Las Lajas } \\
(2 \text { Loa } 76)\end{array}$ & Alero (lado este) & Pintura & 9 \\
\hline & \multirow{2}{*}{$\begin{array}{c}\text { Quebrada de } \\
\text { Caspana }\end{array}$} & $\begin{array}{l}\text { Cueva del Diablo } \\
\text { (2 Loa 91; } \\
\text { 02CAS/CAS58) }\end{array}$ & Alero (lado sur) & Pintura & 1 \\
\hline & & $\begin{array}{l}\text { Máquina Infernal } \\
\quad(2 \text { Loa } 42)\end{array}$ & $\begin{array}{l}\text { Pared cerrada por una } \\
\text { estructura (lado sur) }\end{array}$ & Pintura & 5 \\
\hline & $\begin{array}{l}\text { Quebrada de } \\
\text { Toconce }\end{array}$ & $\begin{array}{c}\text { Likan } \\
\text { (2 Loa 05) }\end{array}$ & $\begin{array}{l}\text { Aleros y pared } \\
\text { (lado sur y este) }\end{array}$ & $\begin{array}{l}\text { Pintura, grabado y } \\
\text { grabado pintado }\end{array}$ & 9 \\
\hline
\end{tabular}


Tabla 2. Características arqueológicas de los sitios analizados. Archaeological characteristics of the sites analyzed.

\begin{tabular}{|c|c|c|c|c|c|}
\hline $\begin{array}{l}\text { Nombre } \\
\text { del Sitio }\end{array}$ & Tipo de Sitio & Dataciones & $\begin{array}{l}\text { Ocupación } \\
\text { del Sitio }\end{array}$ & $\begin{array}{l}\text { Actividades } \\
\text { Asociadas }\end{array}$ & Referencias \\
\hline Agua Mineral & Alero cerrado por una pirca. & $\begin{array}{c}\text { 1.370 d.C. } \\
\text { (cal. 95\%: } 1.300-1.425 \text { d.C.) } \\
\text {-C14, mazorca de maíz- }\end{array}$ & Temporal & $\begin{array}{l}\text { Fabricación } \\
\text { de perlas; } \\
\text { Agricultura }\end{array}$ & $\begin{array}{c}\text { Proy. Fondecyt } \\
1980200\end{array}$ \\
\hline El Diablo & $\begin{array}{l}\text { Alero cerrado por una } \\
\text { pirca, sin excavar, registro } \\
\text { superficial. }\end{array}$ & - & Temporal & $\begin{array}{l}\text { Sitio de } \\
\text { tránsito }\end{array}$ & $\begin{array}{c}\text { Proy. Fondecyt } \\
1979528\end{array}$ \\
\hline Los Mosquitos & $\begin{array}{l}\text { Alero, sin registro } \\
\text { arqueológico superficial. }\end{array}$ & - & Temporal & $\begin{array}{l}\text { Sitio de } \\
\text { tránsito }\end{array}$ & $\begin{array}{c}\text { Proy. Fondecyt } \\
1980200\end{array}$ \\
\hline Incahuasi Inca & $\begin{array}{l}\text { Asentamiento complejo } \\
\text { conformado por distintos } \\
\text { sectores: habitacional, } \\
\text { funerario (chullpas y aleros), } \\
\text { agrícola y de almacenaje } \\
\text { (collcas). }\end{array}$ & $\begin{array}{c}570 \text { d.C. } \\
(1.425 \pm 130 \text { a.p. }) \\
\text { a } 1.480 \pm 50 \text { d.C. } \\
(515 \pm 50 \text { a.p. }) \\
\text {-Dataciones TL sobre } \\
\text { cerámicas- }\end{array}$ & Permanente & Agricultura & $\begin{array}{l}\text { Proy. Fondecyt } \\
\text { 1979528; } \\
\text { Uribe 2002; } \\
\text { Sinclaire 2004 }\end{array}$ \\
\hline Pilpila & $\begin{array}{l}\text { Alero, con cerámica } \\
\text { superficial atribuible al } \\
\text { período Intermedio Tardío. }\end{array}$ & - & Temporal & Pastoreo & \multirow{7}{*}{$\begin{array}{c}\text { Proy. Fondecyt } \\
1980200\end{array}$} \\
\hline Cueva Roja & \multirow[b]{2}{*}{$\begin{array}{l}\text { Conjunto de aleros cerrados } \\
\text { por pircas. }\end{array}$} & - & Temporal & \multirow{4}{*}{$\begin{array}{l}\text { Agricultura y } \\
\text { Pastoreo }\end{array}$} & \\
\hline El Suri & & $\begin{array}{l}\text { 1.180 } 440 \text { d.C. } \\
\text { (cal. 95\%: } 765-970 \text { d.C.) } \\
\text {-C14, carbón-- }\end{array}$ & Temporal & & \\
\hline La Cueva & Alero cercado por una pirca. & - & Temporal & & \\
\hline Las Lajas & Alero cercado por una pirca. & - & Temporal & & \\
\hline $\begin{array}{l}\text { Cueva del } \\
\text { Diablo }\end{array}$ & $\begin{array}{l}\text { Alero cercado por una pirca } \\
\text { y una estructura de piedra } \\
\text { externa utilizada como } \\
\text { corral. }\end{array}$ & - & Temporal & Pastoreo & \\
\hline $\begin{array}{l}\text { Máquina } \\
\text { Infernal }\end{array}$ & $\begin{array}{l}\text { Estructuras habitacionales de } \\
\text { piedras construidas adosadas } \\
\text { a la pared de la quebrada. }\end{array}$ & - & Temporal & Agricultura & \\
\hline \multirow[b]{2}{*}{ Likan } & \multirow[b]{2}{*}{$\begin{array}{l}\text { Asentamiento complejo } \\
\text { conformado por distintos } \\
\text { sectores: habitacional, } \\
\text { funerario (chullpas y aleros), } \\
\text { agrícola y senderos. }\end{array}$} & $\begin{array}{l}850 \text { d.C. a } 1.210 \text { d.C. } \\
\text {-Dataciones TL, sobre } \\
\text { cerámicas- }\end{array}$ & & \multirow[b]{2}{*}{ Funeraria } & $\begin{array}{c}\text { Aldunate y } \\
\text { Castro 1981; } \\
\text { Aldunate et al. } \\
1986\end{array}$ \\
\hline & & $\begin{array}{c}660 \pm 100 \text { d.C. } \\
\text { (cal. } \pm 1 \text { sigma: } 1.216- \\
1.444 \text { d.C.) } \\
905 \pm 95 \text { d.C. } \\
\text { (cal. } \pm 1 \text { sigma: } 1.025- \\
1.261 \text { d.C.) } \\
\text {-C14, fragmentos de } \\
\text { mortero- }\end{array}$ & Permanente & & $\begin{array}{l}\text { Pärssinnen } \\
2005\end{array}$ \\
\hline
\end{tabular}




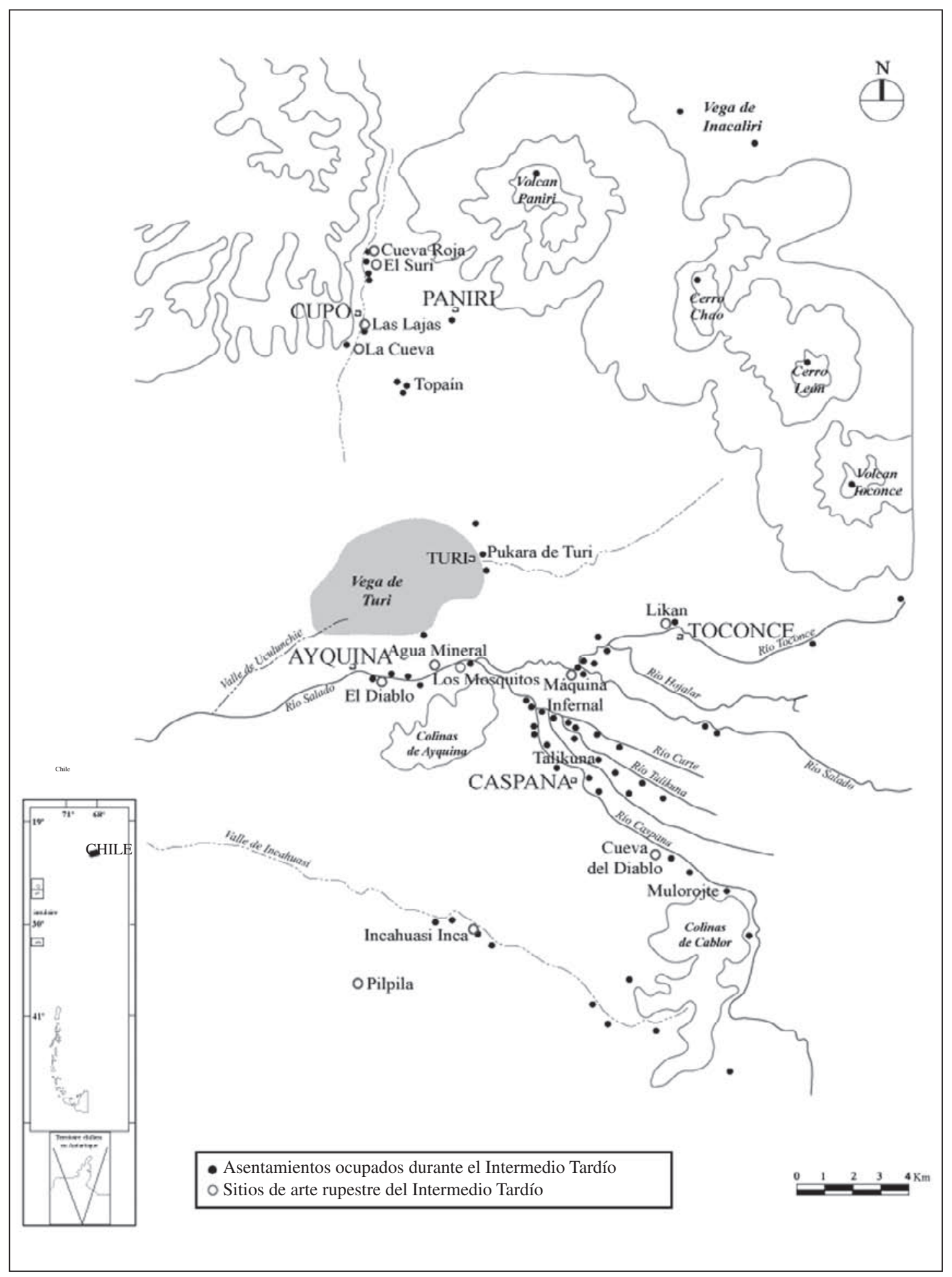

Figura 1. Mapa de localización de los sitios de arte rupestre del período Intermedio Tardío en la Cuenca del río Salado. Map showing the of location of the rock art sites found in the Salado River basin dating to the Late Intermediate Period. 
grabadas y pintadas $(11,1 \%)$ relativas a camélidos cuya silueta fue delimitada por un profundo surco grabado y con el cuerpo pintado en su interior de color rojo. Finalmente, las figuras grabadas corresponden a $0,6 \%$ del total.

En el caso de las pinturas se trata de figuras de pequeño tamaño, $20 \mathrm{~cm}$ aproximadamente, mientras en el caso de los grabados pintados se alcanzan los $30 \mathrm{~cm}$ en promedio. Para las pinturas identificamos el uso de una amplia gama de colores: rojo, naranjo, amarillo, verde, azul, blanco y negro, generalmente usados solos, aunque se hallan escasos ejemplos de bicromía: rojo con blanco, azul con rojo, verde con rojo y amarillo con rojo. El análisis de las pinturas confirmó que en la mayoría de los casos los amarillos, rojos y blancos corresponden a arcillas con cantidades variables de óxidos de fierro; algunos blancos fueron hechos a base de sílice (posibles arenas). Los negros dieron por resultado la presencia de figuras realizadas con carbón de madera (Sepúlveda 2006), mientras que los azules y verdes fueron producidos a partir de minerales de cobre abundantes en la región (Sepúlveda y Laval 2006).

Para la definición de modalidades estilísticas, tomando en cuenta que el universo de estudio correspondía esencialmente a figuras de camélidos $\mathrm{y}$ antropomorfas, se consideraron las siguientes variables: presencia/ausencia de ciertos detalles anatómicos (en el caso de los camélidos, por ejemplo, la curva del vientre o las articulaciones en las patas; en el caso de las figuras antropomorfas la presencia de cintura y/o caderas); la animación de las figuras (presencia/ausencia de movimiento, Gallardo 2004b); las formas de perspectiva utilizadas (absoluta, normal, "semi-torcido", Aujoulat 1993; Vialou 1999); la composición de los paneles en escena, agregado, simetría o ninguno; y en el caso de las figuras antropomorfas, la presencia de ciertos elementos de atuendo como tocado, vestimenta u objetos en las manos (sensu Montt 2005). En este caso particular, se consideró además, en relación con su visibilidad, el emplazamiento de los paneles: al interior o al exterior de los aleros, o sobre las paredes de quebrada, junto con el tamaño de las representaciones.

Con la aplicación de análisis multivariados (Clusters analysis) se combinaron las distintas variables, distinguiendo primeramente por referente, es decir, entre camélidos y figuras antropomorfas, para luego combinarlas cualitativamente según se encontraran asociadas o conformando algún tipo de escenas en un panel. Los análisis efectuados permitieron identificar así tres modalidades estilísticas, mencionando sus principales características:

\section{Modalidad Estilística I (Figura 2)}

Esta modalidad concierne a figuras antropomorfas y de camélidos pintados y de pequeño tamaño $(15-20 \mathrm{~cm})$. Éstas manifiestan generalmente una actitud animada, con la acentuación de ciertos rasgos tales como la curva del vientre y las articulaciones de las patas en el caso de los camélidos, de la cintura y caderas en el caso de las representaciones humanas. Estas últimas pueden portar ciertos elementos de atuendo, esencialmente objetos en las manos y tocados. Además, estas figuras se representan de frente o de perfil. Cuando se hallan de frente es común encontrarlas asociadas a otras figuras de características similares (desde una a más); mientras que de perfil las representaciones antropomorfas se hallan generalmente en acción y asociadas a una figura de camélido atado por una "cuerda"; sin embargo, los camélidos también pueden estar solos en un panel.

Esta modalidad es la más representativa de nuestro universo de estudio y, en términos generales, las figuras que la componen comparten ciertas variables: técnica, tamaño y en algunos casos su organización al interior de un panel. Pese a estas semejanzas, se reconoce en esta modalidad la primacía de una gran heterogeneidad de estilos. Estas formas de representación se encuentran en los aleros de Likan, de Cupo, de Pilpila y de Incahuasi Inca, entre otros. En esta modalidad se reconocen muchos camélidos con atributos y variables formales propios del estilo Confluencia (Gallardo 2001) aunque bajo composiciones totalmente diferentes, pues se trata de figuras generalmente solas y no en escenas. Otra semejanza con un estilo anterior se refiere a la gran cantidad de figuras antropomorfas, en relación a los animales, rasgo de posible remembranza al estilo Cueva Blanca donde se observa un particular énfasis en las composiciones geométricas con personajes humanos (Gallardo et al. 1999; González 2005).

\section{Modalidad Estilística II (Figura 3)}

Esta modalidad agrupa figuras de camélidos caracterizadas por un grueso trazo grabado que 


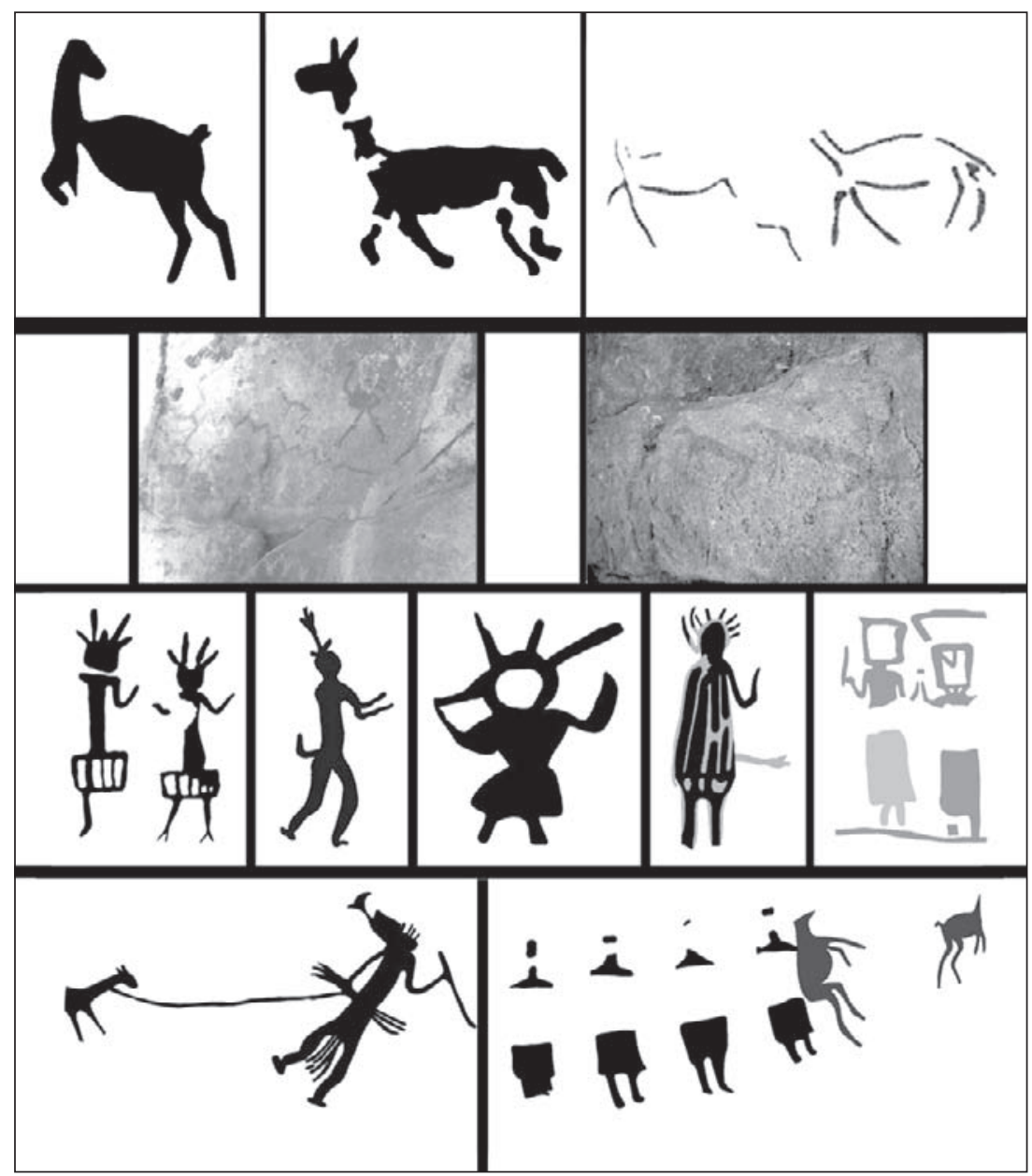

Figura 2. Representaciones rupestres de la Modalidad I. Rock art representations of Modality I.

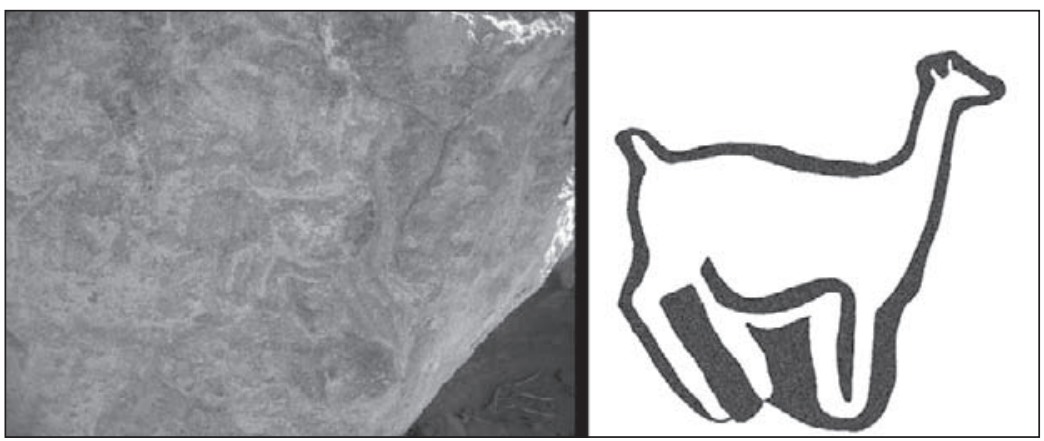

Figura 3. Representaciones rupestres de la Modalidad II.

Rock art representations of Modality II.

delimita sus siluetas y con la presencia, en algunos casos, de pintura al interior de sus cuerpos. Una observación directa hace presumir que todas estas representaciones pudieron tener el cuerpo enteramente pintado de rojo, existiendo graves problemas de conservación de la pintura ${ }^{1}$. Su tamaño puede llegar hasta los $40 \mathrm{~cm}$ de largo. En cuanto a composición, las figuras se encuentran aisladas en un panel. 
Estas formas de camélidos se observan en el sitio de Likan en las paredes externas de los aleros. Esta modalidad presenta rasgos bastante semejantes a las figuras que definen el estilo Taira (Berenguer 1999; Gallardo 2001) en cuanto al profundo surco que delimita cada figura y la presencia, en ciertos casos, de pintura roja en el cuerpo. Sin embargo, en esta Modalidad II se identifican composiciones de paneles diferentes donde priman figuras únicas y de menor tamaño que las de Taira, donde además se hallan figuras antropomorfas.

\section{Modalidad Estilística III (Figura 4)}

Finalmente, esta modalidad reúne figuras pintadas de tamaño pequeño, no más de $15 \mathrm{~cm}$. Se trata de representaciones caracterizadas por la ausencia de rasgos anatómicos, así como de animación, manifestándose de forma mucho más esquemática. En esta modalidad se observan dos tipos de figuras antropomorfas: las primeras caracterizadas por la presencia de variados elementos de atuendo (camisas, tocados y objetos en las manos), siendo las segundas reducidas a un conjunto de simples trazos lineales, pero siempre portando algún tipo de tocado (algunas veces en forma de semiluna o tumi). En relación a los camélidos se observa el uso de distintas formas de perspectivas con la presencia de animales de dos o cuatro patas, con un cuerpo y patas reducidos a simples trazos (Esquema 1 en Sepúlveda 2004), o con el cuerpo representado por una forma rectangular sin curva de vientre y sin articulaciones en las patas (Esquema 3 en Sepúlveda 2004; ver también Sepúlveda 2008). Estas formas de representación se encuentran en Incahuasi Inca, El Diablo, La Cruz y Cueva del Diablo. Se les encuentra en técnica de grabado en otros sitios de la región.

\section{Discusión de Interpretaciones}

Dados los límites impuestos por la imposibilidad de fechar directamente el arte rupestre nos atrevemos a discutir ciertas asociaciones cronológicas y posibles interpretaciones funcionales para las diferentes modalidades identificadas. Siguiendo los tres criterios descritos por Gallardo (1996 [1998]) se integran a la discusión los fechados existentes en algunos contextos y el estudio de los vestigios asociados a las manifestaciones rupestres (criterio de contigüidad); se aplican comparaciones iconográficas entre las figuras analizadas y otras de adscripción cronológica conocida (criterio de semejanza); se consideran, finalmente, los estilos como patrones que estructuran o definen las figuras y sus asociaciones (criterio de contraste).

Por último, se discuten las principales interpretaciones aludidas hasta ahora para el arte

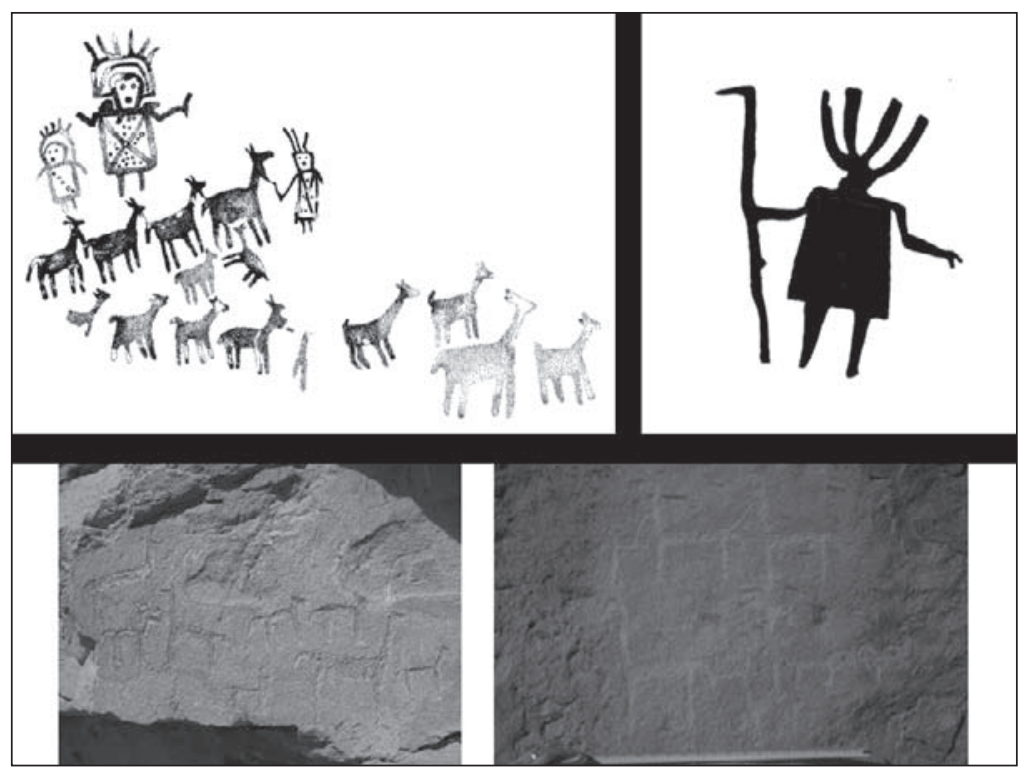

Figura 4. Representaciones rupestres de la Modalidad III. Tomada de Vilches y Uribe (1999). Rock art representations of Modality III. After Vilches and Uribe (1999). 
Tabla 3. Resumen de las atribuciones cronológicas relativas y absolutas de los sitios analizados. Summary of the relative and absolute chronological attributions of the sites analyzed.

\begin{tabular}{|c|c|c|c|c|c|c|c|c|c|}
\hline \multirow[b]{2}{*}{ Sitios } & \multirow[b]{2}{*}{ Modalidades } & \multicolumn{4}{|c|}{ Contextos } & \multicolumn{4}{|c|}{ Dataciones } \\
\hline & & Formativo & $\begin{array}{c}\text { PIT } \\
\text { inicial }\end{array}$ & $\begin{array}{l}\text { PIT } \\
\text { final }\end{array}$ & $\begin{array}{c}\text { Horizonte } \\
\text { Tardío }\end{array}$ & Formativo & $\begin{array}{c}\text { PIT } \\
\text { inicial }\end{array}$ & $\begin{array}{l}\text { PIT } \\
\text { final }\end{array}$ & $\begin{array}{c}\text { Horizonte } \\
\text { Tardío }\end{array}$ \\
\hline Agua Mineral & I & - & $X$ & $\mathrm{X}$ & - & - & - & $X$ & - \\
\hline Cueva del Diablo & III & - & - & $\mathrm{X}$ ? & - & - & - & - & - \\
\hline Cueva Roja & I & - & $\mathrm{X}$ & $X$ & - & - & - & - & - \\
\hline El Diablo & I y III & - & $\mathrm{X}$ ? & $\mathrm{X}$ ? & $\mathrm{X}$ ? & - & - & - & - \\
\hline El Suri & I y III & & $\mathrm{X}$ & $\mathrm{X}$ & $\mathrm{X}$ & $\mathrm{X}$ & $\mathrm{X}$ & - & - \\
\hline Incahuasi Inca & I y III & $X$ & ¿? & $X$ & $\mathrm{X}$ & $X$ & - & $X$ & $X$ \\
\hline La Cueva & I & - & $\mathrm{X}$ & $\mathrm{X}$ & $\mathrm{X}$ & - & - & - & - \\
\hline Las Lajas & I & - & $\mathrm{X} ?$ & - & - & - & - & - & - \\
\hline Likan & I y II & - & $\mathrm{X}$ & $\mathrm{X}$ & - & - & $X$ & - & - \\
\hline Los Mosquitos & I & - & - & $\mathrm{X} ?$ & - & - & - & - & - \\
\hline Máquina Infernal & I & - & - & $\mathrm{X}$ & - & - & - & - & - \\
\hline Pilpila & I & $\mathrm{X}$ ? & - & $X$ & - & - & - & - & - \\
\hline
\end{tabular}

pintado y grabado-pintado del Intermedio Tardío, proponiendo dar mayor énfasis al rol del individuo en la práctica rupestre.

\section{Adscripción cronológica}

De acuerdo con los antecedentes recopilados y resumidos en las Tablas 2 y 3 es posible visualizar que la mayoría de los sitios incluidos en este trabajo se relacionan mayoritariamente con el período Intermedio Tardío. Sólo en los casos de Incahuasi Inca y Pilpila existen evidencias cerámicas atribuibles al Formativo, con una ocupación evidente en el caso del primer sitio. En Incahuasi Inca también existe una fuerte ocupación durante el Horizonte Tardío incaico.

La Modalidad I es el conjunto que reagrupa la mayoría de las figuras consideradas en la muestra analizada, registrándose en varios sitios: Likan, aleros de Cupo (El Suri, Cueva Roja, La Cueva, Las Lajas), Máquina Infernal, Agua Mineral y Pilpila. Las dataciones absolutas existentes son 1.370 d.C. (cal. 95\%: 1.300-1425 d.C.) para Agua Mineral, y $1.180+/-40$ d.C. (cal. $95 \%$ : 765-970 d.C.) para El Suri (Tabla 2), permitiendo por contigüidad atribuir este estilo al período Intermedio Tardío, iniciándose posiblemente durante el Formativo
Tardío. Esta sugerencia es reafirmada por Montt (2005:156-157), quien al analizar los elementos de vestimenta de las figuras antropomorfas plantea que la forma de faldellín continuo observado en las representaciones de Cupo se correlaciona con un momento posiblemente coincidente con el final del Formativo e inicios del Intermedio Tardío.

La Modalidad II se observa sólo en Likan, cuyas dataciones se insertan principalmente en la fase inicial del Intermedio Tardío (Tabla 2), por lo cual podría presumirse su realización en este momento. Apoyando esta hipótesis, se menciona la existencia de camélidos similares con la silueta demarcada con un profundo trazo grabado, aunque sin el cuerpo pintado, en otros dos sitios de la confluencia de los ríos Caspana y Curte: Doña Marta y Las Oquedades. En ambos casos se reconoce en el sitio la presencia de estructuras circulares adosadas a la pared de la quebrada por sobre el talud, encontrándose el arte rupestre al interior de algunas de las estructuras. De estos sitios resulta relevante una única datación obtenida por $\mathrm{C} 14$ sobre una muestra de carbón de Doña Marta, de 740 d.C. (cal. 95\%: 675-980 d.C., Proyecto Fondecyt 1980200). Si se establece una comparación entre las respresentaciones de Likan y Doña Marta, considerando además las dataciones de ambos 
sitios, sería probable pensar en que dichas figuras corresponden a un momento tardío del Formativo e inicios del Intermedio Tardío. Esta adscripción cronológica es ampliada con otros fechados obtenidos en Likan por Pärssinnen (2005) que muestran que la ocupación del sitio perduró bien avanzado el período de Desarrollos Regionales (Tabla 2).

Respecto a la Modalidad III, observado en El Suri, Incahuasi Inca, Cueva del Diablo y El Diablo, se plantea una adscripción cronológica situada entre una fase final del Intermedio Tardío y durante el Horizonte Tardío, tal como ha sido presentado en ocasiones anteriores (Sepúlveda 2004, 2008; ver también Berenguer et al. 2007). La mayor ortogonalidad observada en las representaciones de camélidos y de seres antropomorfos, así como la presencia de figuras antropomorfas portando camisas rectangulares (Montt 2005:133) son elementos a favor de una adscripción tardía de este tipo de manifestaciones durante el siglo XV.

De esta breve exposición, se resume entonces que la Modalidad I puede atribuirse a una fase inicial del período Intermedio Tardío, con quizás algunas incursiones en esta forma de representación desde el Formativo. La Modalidad II también correspondería a algún momento final del Formativo e inicios del Intermedio Tardío. Al otro extremo, la Modalidad III se enmarcaría en un momento tardío del Intermedio Tardío para prolongarse durante el Horizonte Tardío (Tabla 3).

Si bien esta adscripción es hipotética pero muy factible, considerando cierta contemporaneidad, intentaremos reflexionar sobre la función y/o uso de estos estilos, procurando entender la variedad de formas de representación observadas y las tres modalidades identificadas. De este modo, a la interpretación cronológica que explicaría la existencia de diferentes modalidades en el tiempo, proponemos una alternativa relacionada con el uso y/o función del arte rupestre durante el Intermedio Tardío.

\section{Arte rupestre y tráfico de caravanas}

Una de las alternativas más consensuada para interpretar el arte rupestre del Intermedio Tardío concierne a su vínculo con el tráfico de caravanas. La homogeneidad de las formas de representación de la Modalidad III, además de la representación de figuras antropomorfas tirando uno o varios camélidos y portando a veces cargas aludiendo directamente al caravaneo (Núñez 1985:244) son argumentos a favor de esta interpretación. La asociación de los paneles a senderos es también otro aspecto favorable para esta hipótesis, aunque sólo se manifiesta más claramente en el sitio El Diablo.

Sin embargo, a diferencia de los sitios presentados por Núñez (1985) y de otros presentes en el Alto Loa (Berenguer 2004a), la mayoría de los paneles considerados se emplazan al interior de aleros, algunos en penumbra, sin que éstos sean visibles desde fuera. A su escasa visibilidad se suma el hecho de no estar necesariamente asociados a rutas de tráfico local o interregional, factores que hacen necesaria la búsqueda de otra alternativa de interpretación. Un argumento más en contra de esta interpretación se refiere a la escasez de representaciones de camélidos alineados unos tras otros o portando cargas sobre sus lomos.

Si bien algunos sitios hacen referencia a las caravanas y se encuentran próximos a senderos, esta interpretación sólo concierne a una minoría de los casos analizados de la Modalidad III y en ningún caso las Modalidades I y II, debiendo buscarse otra opción.

\section{Arte rupestre y territorialidad}

Esta interpretación ha sido otra de las vías de trabajo explorada para el arte rupestre del Intermedio Tardío (Gallardo et al. 1999; Sepúlveda 2002a, 2002b). Para ello se ha aludido a la relación que mantendría la realización de las representaciones y su presencia al interior de aleros considerados como lugares sagrados (Castro 1997). La ejecución de las pinturas, en ciertos casos, se relacionaría con algún tipo de práctica referida a la necesidad de legitimar la presencia o uso de cierto espacio y/o territorio, muy posiblemente por parte de "sacerdotes indígenas" (Castro 1997). Tal como ha sido planteado para las chullpas en la región (Ayala 1998), cuyo rol sería marcar visiblemente la presencia y quizás la explotación de determinado territorio en la subregión del río Salado, la marcación de los aleros podrían permitir reivindicar la presencia de un sustrato local.

En este caso podría entenderse la heterogeneidad de estilos que conforman la Modalidad I, donde se observa una evidente variabilidad pese a compartir ciertos atributos formales y de composición. Esta diversidad podría, en efecto, correlacionarse con la multietnicidad característica del Intermedio Tardío 
(Schiappacasse et al. 1989), siendo las pinturas rupestres parte de las ceremonias de legitimación ancestral y territorial.

Sin embargo, se trata en su mayoría de espacios pequeños que no permiten la congregación de muchos individuos, siendo difícil pensar en actos comunitarios que reúnan muchas personas. La presencia mayoritaria del arte rupestre, salvo en los sitios de Likan e Incahuasi Inca, en áreas de ocupación con función específica, más pequeños y alejados de la mayoría de los grandes asentamientos, reafirma que estas manifestaciones fueron, sin duda, poco visibles para la mayoría de los individuos, que se concentrarían en torno a las principales aldeas. Los aleros serían utilizados de forma "secundaria", con un uso temporal o efímero en relación con ciertas actividades cotidianas que exigen que los individuos se alejen de sus residencias principales, como es el caso del pastoreo o ciertas actividades agrícolas. Aún así, si bien se acepta esta interpretación, se requiere complementarla con una aproximación contextual de los sitios de arte rupestre.

\section{Arte rupestre del período Intermedio Tardío: ¿un arte de pastores y de individuos?}

Siguiendo con lo anterior, otra alternativa se relaciona con la necesidad de evaluar con mayor énfasis los aspectos de visibilidad de los sitios y figuras, así como el tipo de actividades realizadas en los espacios donde se ubica el arte rupestre analizado.

Previamente, se mencionó que la mayoría de las figuras son de pequeño tamaño y se encuentran en espacios de poca visibilidad. Esto sugiere una necesaria cercanía para la percepción de las representaciones, hasta una relación estrecha con el espacio donde se plasman determinadas imágenes.

En relación a la Modalidad I, la de mayor diversidad y la que agrupa la mayor cantidad de figuras, se observa que los contextos asociados a las representaciones denotan actividades ligadas al pastoreo o bien a prácticas agrícolas (aleros de Cupo, Agua Mineral, Pilpila, Incahuasi Inca, entre otros). También se observan representaciones en espacios de uso funerario (Likan). En la mayoría de los casos se trata de contextos que si bien plantean un uso con una finalidad o beneficio colectivo (almacenaje de cosechas, cuidado del ganado, ceremonias funerarias con una posible relación a actos ligados con los ancestros y definición de pertenencia), son de utilización más bien individual. Respecto a las imágenes representadas se observa la reiteración de ciertos temas. Por ejemplo, en la Modalidad I se identifica la presencia de camélidos sin cargas sobre sus lomos y atados por una cuerda a una figura antropomorfa, tratándose en su mayoría de un solo animal y pudiendo traducir una escena en la cual se plasma cierta cercanía entre un posible pastor y un camélido. La presencia de aves es también observada en ciertos paneles con camélidos, siendo esta cercanía también remarcada en los pastores de la sierra peruana (Palacios 2000). Así, diversos elementos nos remiten fuertemente a la representación de actividades ligadas al pastoreo, una actividad muy común en la subregión del río Salado y favorecida por la presencia de vegas (Figura 1).

Otro tema reiterado en la Modalidad I se refiere a la representación de figuras antropomorfas similares, de frente y alineadas unas al lado de otras, relacionando la mayoría de las veces sólo dos individuos y sin asociación a animales. La presencia de una cantidad mayoritaria de figuras antropomorfas en la Modalidad I, a diferencia de las Modalidades II y III o de los estilos Taira Tulan y Confluencia identificados en la región donde siempre son mayoritarias las figuras animales (y esencialmente las de camélido), podrían estar sugiriendo para el Intermedio Tardío una mayor importancia de los seres humanos, sin que podamos todavía identificar su rol preciso al interior de la sociedad. Esta predominancia quizás corresponda a una continuidad de un énfasis nacido en el estilo Cueva Blanca (González 2005), correspondiente al Formativo (Gallardo et al. 1999), y donde se observa una clara disminución de las figuras animales.

De estas observaciones, se recalca que el arte rupestre se inserta en espacios ligados a prácticas de actividades cotidianas, con el posible énfasis en la representación de escenas ligadas al pastoreo, y otras donde el individuo es el referente principal. Su pequeño tamaño y su emplazamiento en espacios relativamente restringidos, tanto por su tamaño como por su emplazamiento y su localización al interior de espacios muy cerrados, nos hablan de un arte rupestre hecho para ser poco visible y quizás acotado a unos pocos individuos.

\section{Discusión y Conclusión}

Durante el Intermedio Tardío se identifican al menos tres Modalidades de arte rupestre, las 
cuales comparten tantos atributos de formas como de composición, visibilidad y emplazamiento, persistiendo aún así bastante heterogeneidad. La Modalidad I comparte suficientes atributos como para conformar un gran conjunto coherente aunque agrupando estilos muy variables. La Modalidad II resulta aún muy poco representativa como para intentar cualquier interpretación; siendo, sin duda, las representaciones que debieran recibir mayor atención en el futuro. La Modalidad III, más esquemática, pareciera relacionarse con procesos regionales ligados muy probablemente a la movilidad de caravanas; aunque no se descarta que parte de las representaciones se relacionen con procesos relacionados a la expansión del Inka (Berenguer et al. 2007; Sepúlveda 2004, 2008; Vilches y Uribe 1999).

Con este análisis se define que el arte rupestre muestra similitudes evidenciadas por la definición de tres Modalidades Estilísticas, I, II y III; sin embargo, subsiste una variabilidad intrarregional, marcada más aún por la gran heterogeneidad de figuras que componen la Modalidad I. ¿Qué sucede con nuestras expectativas mencionadas al inicio de este trabajo?

En comunidades de pastores en Sudáfrica se observa una heterogeneidad en el arte rupestre durante los períodos caracterizados por un mayor estrés de recursos debido a cambios climáticos y al progresivo aumento demográfico (Brandt y Carder 1987). En nuestro caso, si entendemos el período Intermedio Tardío como un período caracterizado por una creciente complejidad social con la coexistencia de diferentes grupos, acompañada por la demanda de ciertos recursos y consecuente con una territorialidad más marcada, se puede efectivamente pensar que el arte rupestre pudo jugar un rol importante enmarcándose en la realización de rituales comunitarios, cumpliéndose así con nuestra primera expectativa. Estas prácticas habrían permitido cohesionar a una localidad a la vez que reafirmar su pertenencia a un determinado territorio y legitimar su explotación (ver caso similar en Australia, Smith 1992). En nuestro caso, a esto podrían sumarse otras soluciones como el aumento del almacenaje, un desarrollo más masivo de la agricultura y redes de interacción más acotadas (Núñez y Dillehay 1995 [1979]) y manifestaciones funerarias visibles como son las chullpas (Ayala 1998).

Sin embargo, la diversidad en el arte rupestre es tal que no pareciera ni siquiera existir cierta homogeneidad al interior de las diferentes localidades de la subregión del río Salado, refutándose de paso nuestra expectativa 2. Si bien las representaciones analizadas comparten ciertos atributos quizás producto de la interacción manifestada durante la época de Desarrollos Regionales, se observan formas por lo general muy diversas. La expectativa 2 sólo se cumpliría en la Modalidad III donde las figuras muestran bastante coherencia y homogeneidad producto del caravaneo y/o de la entrada de influencias incaicas.

En nuestro caso, el pequeño tamaño de las pinturas, sumado en ciertos casos a sus emplazamientos, nos induce a pensar que no se trata de un arte realizado para ser visible de lejos o ser visto por muchos. El análisis de pigmentos, por su lado, también nos muestra una gran diversidad de formas de producir la pintura como si cada artista confeccionara su pote de pintura individualmente; tal cual aprendió, pero sin repetir un patrón preestablecido (Sepúlveda 2006) y quizás condicionado por la disponibilidad de recursos presentes al momento de ejecutarse una representación sobre una pared. Durante el Intermedio Tardío, a diferencia de los estilos más normados del Formativo (Gallardo 2001; González 2005), se identifican a nivel formal y de composición diferentes modalidades con una gran variabilidad y heterogeneidad estilística interna que pareciera traducirse en prácticas individuales, casi íntimas, compartiendo solamente su emplazamiento y su pequeño tamaño.

Sin duda que lo más interesante de este estudio gira en torno al arte rupestre de la Modalidad I, la cual pareciera efectivamente insertarse más dentro de prácticas acotadas a uno o pocos individuos con la representación de imágenes que en ciertos casos son "ejemplos de creatividad representacional e innovación técnica, soluciones únicas, figuras que no se ajustan a la tradición [...] expresiones de una estética privada" (Mege 2000:41). Tal vez, durante el Intermedio Tardío como en ningún otro momento de la prehistoria de la subregión del río Salado, el acto de recreación del "artista" encuentre su lugar como modo de expresión frente a un contexto sociopolítico complejizante, quizás en espacios de remembranzas pasadas (Castro 1997). La reminiscencia de ciertos atributos o elementos de representación del período Formativo anterior (ver descripción de Modalidades; Sepúlveda 2002b:86, 106 y 127, 2006:245) nos muestra la persistencia de una tradición de representación iniciada milenios 
antes, pero que genera formas de innovación y originalidad $^{2}$ (ver también Montt 2004:657).

Después de varios milenios de manejar una forma de expresión rupestre, es posible que el arte del Intermedio Tardío, en la subregión del río Salado, no sea más que una forma de poder rescatar al individuo en su expresión de creatividad individual, permitiéndonos entender que detrás de actos de reproducción e innovación existe un agente creativo (Hodder 2000). Si entendemos el estilo como un acto de recreación (Voss y Young 1995:95), se corresponde que no necesariamente deba existir un patrón definido estricto sino un conjunto de normas, con múltiples opciones de expresión y entre las cuales el individuo escoge. Entendemos que una modalidad puede agrupar diferentes estilos que reflejan, entonces, un proceso de elección no en términos de escoger entre alternativas funcionales similares (Sackett 1977, 1985, 1990), sino en términos de opciones de representación y lo cual para expresarse debe manifestarse en un cierto dominio de validez (Benveniste 1995, ver también Gallardo 2001). Tal como lo expusiéramos en el inicio de este trabajo y como lo plantea Lévi-Strauss (1979:127), el individuo crea la ilusión de su originalidad; sin embargo, éste nunca actúa solo, replica creadores pasados o presentes, actuales o virtuales [...] no [andando] nunca sólo por el sendero de la creación. El arte rupestre es una manifestación activa y comunicativa que al insertarse en ciertos espacios adquiere su validez para quienes transiten ante él.

Rompiendo con las tendencias evolucionistas que han tendido a identificar un estilo para un período, los análisis efectuados en la región de Atacama dan cuenta que el arte rupestre se relaciona con procesos complejos, pudiendo existir modalidades y estilos contemporáneos que manifiestan prácticas, intereses o modos de vida diferentes (p.ej., Gallardo 2004a; Gallardo y Yacobaccio 2007). Es así como ahondando más profundamente en las formas de aproximarse al arte rupestre, en este caso del Intermedio Tardío, se entiende que las soluciones gráficas identificadas en Modalidades traducen opciones diferentes de representación aludiendo posiblemente a diversas prácticas, tales como la agricultura, la ganadería, el caravaneo o actividades ceremoniales; pero también a diferentes autores de las obras estudiadas, donde al fin puede expresar actos de recreatividad en actos necesarios de identificación y definición social o étnica. Ese individuo corresponde muy posiblemente a algún "sacerdote indígena" (Castro 1997) o algún pastor, cuyos actos adquirían su eficacia simbólica justamente en espacios pequeños y sagrados de tránsito cotidiano, aunque acotados a algunos individuos.

Este ejercicio constituye un eslabón más en la comprensión de los procesos de coexistencia étnica acontecida durante el Intermedio Tardío y que abarca regiones mucho más amplias. La subregión del río Salado no es un espacio aislado; muy por el contrario, se sitúa en la intersección de muchas influencias que combinadas a lo local manifiestan una importante riqueza de información arqueológica que aún falta por pesquisar. Quizás el arte rupestre sea más que simples motivos pintados o grabados sobre paredes y pueda insertarse en la discusión identitaria del individuo, pero también social y de multietnicidad característica del Intermedio Tardío (ver también Cases 2008), permitiendo abordar la complejidad observada en ese período.

Estos momentos de creatividad e individualidad del Intermedio Tardío serían finalmente perturbados por la pronta llegada de influencias incaicas, definiéndose un patrón cada vez más ortogonal y sintético, cercano a la Modalidad III, con un patrón de reproducción masiva sobre distintos soportes y en distintas regiones del Tawantinsuyu (Sepúlveda 2008).

Agradecimientos: Proyecto Fondecyt 1070083. Este trabajo resume en parte la investigación iniciada el año 2000 y que diera origen a la realización de una tesis doctoral en Francia (2006) financiada por una beca CONICYT-Ambassade de France. Agradezco a los que, a lo largo de estos años, han compartido de cerca o de lejos la concretización de este trabajo. Sus palabras, pensamientos y/o consejos se encuentran parcialmente plasmados en este escrito. Quedo en deuda...Finalmente, mi profunda gratitud a los evaluadores por sus innumerables aportes, sin los cuales este trabajo estaría incompleto. 


\section{Referencias Citadas}

Adán, L. y M. Uribe

1995 Cambios en el uso del espacio en los períodos agroalfareros: un ejemplo en ecozona de quebradas altas, la localidad de Caspana (Provincia el Loa, II Región). Actas del II Congreso Chileno de Antropología, Tomo II, pp. 541555, Colegio de Antropólogos de Chile, Valdivia.

Adán, L., M. Uribe, P. Alliende y N. Hermosilla

1995 Entre el Loa y San Pedro: nuevas investigaciones arqueológicas en la localidad de Caspana (Provincia el Loa, II Región, Chile). Actas del XIII Congreso Nacional de Arqueología Chilena. Hombre y Desierto, una Perspectiva Cultural 9:147-158. Antofagasta.

Aldunate, $\mathrm{C}$.

1991 Arqueología del Pukara de Turi. Actas del XII Congreso Nacional de Arqueología Chilena. Boletín del Museo Regional de la Araucanía 4 (2):61-77. Temuco.

Aldunate, C. y V. Castro

1981 Las Chullpa de Toconce y su Relación con el Poblamiento Altiplánico en el Loa Superior, Período Tardío. Memoria para optar al grado de Licenciado en Filosofía, mención Prehistoria y Arqueología. Editorial Kultrún Ltda., Santiago.

Aldunate, C., J. Berenguer, V. Castro, L. Cornejo, J.L. Martínez y C. Sinclaire

1986 Cronología y Asentamiento en la Región del Loa Superior. Dirección de Investigación y Bibliotecas de la Universidad de Chile, Santiago.

Aldunate, C., J. Berenguer y V. Castro

1983 Estilos de arte rupestre en el Alto Loa. Creces 4 (3): 22-28.

Aschero, C.

2000 Figuras humanas, camélidos y espacios en la interacción Circumpuneña. En Arte en las rocas. Arte rupestre, menhires y piedras de colores en Argentina, editado por M. M. Podestá y M. de Hoyos, pp. 15-44. Sociedad Argentina de Antropología y Asociación Amigos del Instituto Nacional de Antropología y Pensamiento Latinoamericano, Buenos Aires.

Ayala, P.

1998 Apropiación y transformación de arquitectura altiplánica en la región del Loa Superior: la aldea de Talikuna. Actas del XIV Congreso Nacional de Arqueología Chilena, pp. 793-813 Museo Regional de Atacama, Copiapó.

1999 Modalidades de ocupación del espacio durante los períodos Intermedio Tardío y Tardío (900-1.560 d.C.) en la subregión del río Salado (II Región). Informe final Proyecto Fondecyt 1980200.

Aujoulat, N.

1993 La perspective. En L'Art Pariétal Paléolithique. Techniques et Méthodes d'Étude, editado por Groupe de Réflexion sur l'Art Pariétal Paléolithique, pp. 281-288. Paris.

Barthel, T., C. Munizaga y A. Medina

1959 Nota preliminar sobre las pinturas parietales de los refugios de Sirantur. Separata $N^{\circ} 3$ del Boletín Americanistas, p. 171-174, Barcelona.

Benveniste, E.

1995 Semiología de la lengua. En Problemas de Lingüística General, Tomo II, pp. 47-69. Siglo Veintiuno editores, México D.F.
Berenguer, J.

1994a Asentamientos, caravaneros y tráfico de larga distancia en el norte de Chile: el caso de Santa Bárbara. En De Costa a Selva: Intercambio y Producción en los Andes Centro-Sur, editado por M.E. Albeck, pp. 17-50. Instituto Interdisciplinario Tilcara, Tilcara.

1994b Impacto del caravaneo prehispánico tardío en Santa Bárbara, Alto Loa. Actas del XIII Congreso Nacional de Arqueología Chilena. Hombre y Desierto, una Perspectiva Cultural 9:185-202. Antofagasta.

1999 El evanescente lenguaje del arte rupestre en los Andes atacameños. En Arte Rupestre en los Andes de Capricornio, editado por J. Berenguer y F. Gallardo, pp. 9-56. Museo Chileno de Arte Precolombino, Santiago.

2004a Caravanas, Interacción y Cambio en el Desierto de Atacama. Sirawi Ediciones, Santiago.

2004b Cinco milenios de arte rupestre en Los Andes atacameños: imágenes para lo humano, imágenes para lo divino. Boletín del Museo Chileno de Arte Precolombino 9:75-108.

Berenguer, J., V. Castro, C. Aldunate, C. Sinclaire y L. Cornejo 1985 Secuencia del arte rupestre en el Alto Loa: una hipótesis de trabajo. En Estudios en Arte Rupestre - Primeras jornadas de Arte y Arqueología; editado por C. Aldunate, J. Berenguer y V. Castro, pp. 87-108. Museo Chileno de Arte Precolombino, Santiago de Chile.

Berenguer, J., G. Cabello y D. Artigas

2007 Tras la pista del Inca en petroglifos paravecinales al Qhapacñan en el Alto Loa, norte de Chile. Chungara Revista de Antropología Chilena 39:29-49.

Bourdieu, P.

2000 La Distinction. Les éditions de Minuit, Paris.

Brandt, S. y N. Carder

1987 Pastoral rock art in the Horn of Africa: making sense of udder chaos. World Archaeology 19:194-213.

Cases, B.

2008 Mirando las túnicas pintadas de la cuenca media y alta del Loa desde Quillagua (norte de Chile). Manuscrito en posesión de la autora.

Castro, V.

1997 Huacca Muchay: Evangelización y Religión Andina en Charcas Atacama La Baja. Tesis para optar al Grado de Magister en Historia, mención Etnohistoria. Facultad de Filosofía y Humanidades, Departamento de Ciencias Históricas, Universidad de Chile, Santiago.

Castro, V., F. Maldonado y M. Vásquez

1991 Arquitectura del "Pukara" de Turi. Actas del XII Congreso Nacional de Arqueología Chilena. Boletín del Museo Regional de la Araucanía 4 (2):79-102. Temuco.

Davis, W.

1990 Style and history in art history. En The Use of Style in Archaeology; New Directions in Archaeology, editado por M. Conkey y C. Harstof, pp. 18-31. Cambridge University Press, Cambridge.

Gallardo, F.

1996 Acerca de la interpretación de arte rupestre. Boletín de la Sociedad Chilena de Arqueología 23:31-33.

2001 Arte rupestre y emplazamiento durante el Formativo Temprano en la cuenca del río Salado (desierto de Atacama, Norte de Chile). Boletín del Museo Chileno de Arte Precolombino 8:83-98. 
2004a El arte rupestre como ideología: un ensayo acerca de pinturas y grabados en la localidad del río Salado (desierto de Atacama, Norte de Chile). Actas del XV Congreso Nacional de Arqueología Chilena. Chungara Revista de Antropología Chilena Vol. 36 Número Especial, Tomo I, pp. 427-440.

2004b Apuntes sobre el movimiento y su expresión en el arte rupestre del norte de Chile. Boletín de la Sociedad Chilena de Arqueología 37:19-24.

Gallardo, F. y F. Vilches

1995 Nota acerca de los estilos de arte rupestre en el Pukara de Turi (Norte de Chile). Boletín de la Sociedad Chilena de Arqueología 20:26-28.

1998 Pinturas rupestres formativas en la subregión del río Salado, Norte de Chile. Manuscrito en posesión de los autores.

Gallardo, F. y H. Yacobaccio

2007 ¿Silvestres o domesticados? Camélidos en el arte rupestre Formativo Temprano en el desierto de Atacama (norte de Chile). Boletín del Museo Chileno de Arte Precolombino 12 (2):9-31.

Gallardo, F., C. Sinclaire y C. Silva

1999 Arte rupestre, emplazamiento y paisaje en la Cordillera del desierto de Atacama. En Arte Rupestre en los Andes del Capricornio, editado por J. Berenguer y F. Gallardo, pp. 57-96. Museo Chileno de Arte Precolombino, Santiago.

Gallardo, F., I. Montt, M. Sepúlveda y G. Pimentel

2006 Nuevas perspectivas en el estudio de arte rupestre en Chile. Boletín de la Bolivian Rock Art Research Society 20:77-87.

Gallardo, F., F. Vilches, L. Cornejo y C. Rees

1996 [1998] Sobre un estilo de arte rupestre en la cuenca del río Salado (Norte de Chile): un estudio preliminar. Chungara 28:353-364.

González, P.

2005 Códigos visuales de las pinturas Cueva Blanca: formas, simetría y contexto. Boletín del Museo Chileno de Arte Precolombino 10 (1):55-72.

Hegmon, M.

1992 Archaeological research on style. Annual Review of Anthropology 21:517-536.

Hodder, I.

1982 Symbolic and Structural Archaeology. Cambridge University Press. New York.

2000 Agency and individuals in long term processes. En Agency in Archaeology, editado por M.A. Dobres y J. Robb, pp. 21-33. Routledge, Londres.

Jochim, M.A.

1983 Paleolithic cave art in ecological perspective. En Hunther-Gatherer Economy in Prehistory: An European Perspective, editado por G.N. Bailey, pp. 212-219. Cambridge University Press, Cambridge.

Le Paige, G.

1957-58 Petroglifos. Antiguas culturas atacameñas en la cordillera: época neolítica. Anales de la Universidad Católica de Valparaíso 4-5, Valparaíso.

Lévi-Strauss, C.

1979 La Voie des Masques. Agora, Librairie Plon, Paris.

Lumbreras, L.G.

1974 Los reinos post-Tiwanaku en el área altiplánica. Revista del Museo Nacional de Lima Tomo XL:56-85, Lima.
Manríquez, V.

1999 El término Ylla y su potencial simbólico en el Tawantinsuyu. Una reflexión acerca de la presencia inca en Caspana (río Loa, desierto de Atacama). Estudios Atacameños 18:107-118.

Mege, $\mathrm{P}$.

2000 Originales contra la fuerza. Boletín de la Sociedad Chilena de Arqueología 30:41-47.

Montt, I.

2002 Faldellines del período Formativo en el Norte Grande. Un ensayo acerca de la historia de su construcción visual. Estudios Atacameños 23:7-22.

2004 Elementos de atuendo e imagen rupestre en la subregión del río Salado, norte Grande de Chile. Actas del XV Congreso Nacional de Arqueología Chilena. Chungara Revista de Antropología Chilena Vol. 36 Número Especial, Tomo II, pp. 651-662.

2005 Vestimenta en la Cultura Visual Tardía del Desierto de Atacama. Memoria para optar al Título Profesional de Arqueóloga, Universidad de Chile, Santiago.

Mostny. G.

1966 Ideas mágico-religiosas de los Atacamas. Boletín del Museo Nacional de Historia Natural 30:133-140.

Niemeyer, $\mathrm{H}$.

1968 Petroglifos del río Salado o Chuschul (San Pedro de Atacama, Depto. del Loa, Prov. de Antofagasta, Chile). Boletín de Prehistoria de Chile 1:85-92.

Núñez, L.

1985 Petroglifos y tráfico de caravanas. En Estudios de Arte Rupestre -Primeras jornadas de Arte y Arqueología-, editado por C. Aldunate, J. Berenguer y V. Castro, pp. 243264. Museo Chileno de Arte Precolombino, Santiago.

Núñez, L. y T. Dillehay

1995 [1979] Movilidad Giratoria, Armonía Social y Desarrollo en los Andes Meridionales: Patrones de Tráfico e Interacción Económica. Universidad Católica del Norte, Antofagasta.

Núñez, L., I. Cartajena, J. Loo, S. Ramos, T. Cruz, Th. Cruz y H. Ramírez

1997 Registro e investigación del arte rupestre en la Cuenca de Atacama (informe preliminar). Estudios Atacameños 14:307-325.

Núñez, L., I. Cartajena, C. Carrasco, P. De Souza y M. Grosjean

2006 Patrones, cronología y distribución del arte rupestre Arcaico Tardío y Formativo Temprano en la cuenca de Atacama. En Tramas en la Piedra. Producción y Usos del Arte Rupestre, editado por D. Fiore y M.M. Podestá, pp. 191204, Sociedad Argentina de Antropología, Asociación de amigos del Instituto Nacional de Antropología, Buenos Aires.

Orellana, M.

1963 Las pinturas rupestres del alero de Aiquina. Revista Mapocho 3:153-158.

Palacios, F.

2000 El simbolismo de las alpacas: ritual y cosmovisión andina. En Pastoreo Altoandino. Realidad, Sacralidad y Posibilidades, editado por F. Ochoa y Y. Kobayashi, pp. 189199. PLURAL/ MUSEF, La Paz.

Pärssinnen, M.

2005 Caquiaviri y la Provincia Pacasa. Desde el Alto Formativo hasta la Conquista Española (1-1.533). Colección: Maestría 
en Historias Andinas y Amazónicas Vol. 6. Producciones Cima editores, La Paz.

Rydén, $\mathrm{S}$.

1944 Contributions to the Archaeology of the Rio Loa Region. Gotemburgo: Erlanders Bocktyryckeri Aktiebolag.

Sackett, J.

1977 The meaning of style in archaeology: A general model. American Antiquity 42:360-380.

1982 Approaches to style lithic archaeology. Journal of Anthropological Archaeology 1:59-112.

1985 Style and ethnicity in the Kalahari: A reply to Wiessner. American Antiquity 50:154-159.

1990 Style and and ethnicity in archaeology: The case of isochrestism. En The Uses of Style in Art History, editado por M. Conkey y C. Hastorf, pp. 32-43. Cambridge University Press, Cambridge.

Schiappacasse, V., V. Castro y H. Niemeyer

1989 Los desarrollos regionales en el Norte Grande (1.0001.400 d.C). En Culturas de Chile; Prehistoria, desde sus Orígenes hasta los Albores de la Conquista, editado por J. Hidalgo, V. Schiappacasse, H. Niemeyer, C. Aldunate e I. Solimano, pp. 181-220. Editorial Andrés Bello, Santiago.

Sepúlveda, M.

2002a Peintures rupestres du bassin du río Salado (nord du Chili): Période Intermédiaire Tardive (PIT). International Newsletter on Rock Art 31:22-31.

2002b Imagen Rupestre y Espacialidad en el Desierto de Atacama durante los Períodos Tardíos (950-1550 d.C.). Memoria para optar al título de Arqueóloga, Universidad de Chile, Santiago.

2004 Esquemas visuales y emplazamiento de las representaciones rupestres de camélidos del Loa Superior en tiempos incaicos. ¿Una nueva estrategia de incorporación de este territorio al Tawantinsuyu? Chungara Revista de Antropología Chilena 36:437-449.

2006 Art Rupestre et Iconographie dans le Bassin de la Riviere Salado (Nord du Chili), à la Période Intermédiaire Tardive (850-1450 apr. J.-C.). Thèse Doctorale en Archéologie, UFR 03: Histoire de l'Art et Archéologie, Université Paris 1-Panthéon Sorbonne, France.

2008 Arte rupestre en tiempos incaicos: nuevos elementos para una vieja discusión. En Lenguajes Visuales de los Incas, editado por P. González y T. Bray; BAR International Series 1848: 111-124. Archaeopress, Oxford.

2011 Estilo v/s agencia: rescate del individuo en la práctica rupestre. En Teoría Arqueológica en Sudamérica: Reflexionando en torno a nuestro quehacer disciplinario (título tentativo), editado por F. Vilches y P. Ayala. Ediciones Universidad Católica del Norte, San Pedro de Atacama, en prensa. Sepúlveda, M. y E. Laval

2006 Uso de minerales de cobre en la pintura rupestre de la localidad del río Salado (II Región, norte de Chile). Actas del XVIII Congreso Nacional de Arqueología Chilena, Valdivia, en prensa.
Sinclaire, C.

2004 Prehistoria del Período Formativo en la cuenca alta del Río Salado (Región del Loa Superior). Actas del XV Congreso Nacional de Arqueología Chilena. Chungara Revista de Antropología Chilena Vol. 36 Número Especial, Tomo II, pp. 619-640.

Smith, C.

1992 The articulation of style and social structure in Australian aboriginal art. Australian Aboriginal Studies 1:28-34.

Spahni, J.-C.

1976 Gravures et peintures rupestres du Désert d'Atacama (Chili). Bulletin de la Société Suisse d'Américanistes 40: 29-35.

Troncoso, A.

2002 Estilo, arte rupestre y sociedad en la zona central de Chile. Complutum 13:135-153.

Uribe, $\mathrm{M}$.

1997 La alfarería de Caspana en relación a la prehistoria tardía de la subárea circumpuneña. Estudios Atacameños 14: 243-262.

2002 Sobre alfarería, cementerios, fases y procesos durante la prehistoria tardía del desierto de Atacama (800-1.600 d.C.). Estudios Atacameños 22:7-31.

Uribe, M. y L. Adán

2005 Arqueología e historia... Cultura y evolución social en el desierto de Atacama (900-1.700 d.C.). Actas del XVI Congreso Nacional de Arqueología Chilena, pp. 263-274. Museo de Historia Natural de Concepción, Escaparate Ediciones, Concepción.

Uribe, M., L. Adán y C. Agüero.

2004 Arqueología de los períodos Intermedio y Tardío de San Pedro de Atacama y su relación con la cuenca del río Loa. Chungara Revista de Antropología Chilena. Vol. 36 Especial Tomo II, 943-956.

Vialou, D.

1999 L'art paléolithique. En La Préhistoire, editado por M. Otte, pp. 212-289. De Boeck Université, Bruxelles.

Vilches, F. y M. Uribe

1999 Grabados y pinturas del arte rupestre Tardío de Caspana. Estudios Atacameños 18:73-87.

Voss, J. y R. Young

1995 Style and the self. En Style, Society and Person. Archaeological and Ethnological Perspectives, editado por C. Carr y J.E. Neitzel, pp. 77-99. Plenum Press, New York.

Wiessner, P.

1983 Style and social information in Kalahari San projectile points. American Antiquity 49:253-276.

1985 Style or isochrestic variation? A reply to Sackett. American Antiquity 50:160-166.

1990 Is there a unity of style? En The Uses of Style in Archaeology, editado por M. Conkey y C. Harstorf, pp. 105112. Cambridge University Press, Cambridge.

Wobst, H.

1977 Stylistic behaviour and information Exchange. Anthropological papers of the University of Michigan 61: 317-342. 


\section{Notas}

1 El análisis de una muestra de pintura de uno de estos camélidos del sitio de Likan muestra que se habría utilizado una mezcla un tanto distinta de las otras pinturas muestreadas. En efecto, pudimos determinar que se trata de una pintura a base de arcilla (aluminosilicato potásico y magnésico) con bastante presencia de óxidos de fierro (con la particularidad de sus formas en plaquetas de $7,5 \mu \mathrm{m}$ máximo y burbujas de $-0,5 \mu \mathrm{m})$. Otra particularidad fue la presencia de apatita (fosfato de calcio) correspondiente a restos de fragmentos óseos, visibles en las imágenes obtenidas por microscopio de barrido. La mezcla empleada en esta figura se distingue notoriamente de las demás pinturas del sitio (otras cinco muestras), y la presencia de ciertos componentes podría explicar su mala conservación, sin que hayamos podido ahondar en el tema (Sepúlveda 2006).

2 Una discusión similar es llevada a cabo por Manríquez en torno al concepto de Ylla. En su análisis la autora destaca la larga tradición de uso del concepto, sus diferentes aceptaciones y usos. "Proponemos la idea de que Ylla [...] compartido por el común de los hombres andinos, pudiendo detectarse en distintos niveles de vida de estas poblaciones, las cuales a su vez realizaban un acto de creación al seleccionar, transferir y readecuar ciertos contenidos compartidos por todas las poblaciones andinas, pero atribuyéndoles determinadas cualidades que relacionaban el término Ylla con lo más esencial del Tawaitinsuyu, dentro de una concepción sacralizada de la vida" (Manríquez 1999:114). 